\title{
Sensitivity of Fish Pathogenic Bacteria to Almond (Terminalia Catappa) Leaves and Bitter (Vernonia Amygdalina) Leaves
}

\section{Extracts}

\author{
Fakoya $\mathrm{S}^{1}$, Olusola $\mathrm{SE}^{2 *}$ and Arifalo OV ${ }^{1}$ \\ ${ }^{1}$ Department of Biological Sciences (Microbiology Programme), Ondo State University \\ of Science and Technology, Nigeria \\ ${ }^{2}$ Department of Biological Sciences (Fisheries and Aquaculture Programme), Ondo \\ State University of Science and Technology, Nigeria
}

\section{Research Article \\ Volume 3 Issue 1}

Received Date: December 21, 2018

Published Date: February 04, 2019

DOI: $10.23880 /$ ijoac- 16000158

*Corresponding author: Olusola Sunday Emmanuel, Department of Biological Sciences (Fisheries and Aquaculture Programme), Ondo State University of Science and Technology, Nigeria, Tel: 2348034110139; 2348051026979; Email: belloolus@yahoo.com

\section{Abstract}

The use of antibiotics in aquaculture to treat infection has resulted into the development of resistant strains which have rendered antibiotic treatment ineffective. Therefore, alternative ways of treating diseases must be found, this study aimed to evaluate the antimicrobial activities of almond (Terminalia catappa) leaves and bitter (Vernonia amygdalina) leaves extracts on some fish pathogens such as Staphylococcus aureus, Staphylococcus albus, Pseudomonas aeruginosa, Bacillus subtilis, Aeromonas hydrophila, Escherichia coli, Salmonella typhii, Streptococcus iniae and Aspergillus niger using well-diffusion method. Phytochemical screening and minimum inhibitory concentration of methanolic and ethanolic extracts of $T$. catappa and $V$. amygdalina leaves were determined using standard methods. Data were analyzed using descriptive statistics. The result of the study revealed the diameter of inhibition zone in methanolic and ethanolic extracts of almond leaves while no diameter of inhibition of zone were recorded for S. albus, B. subtilis, A. hydrophila, S. typhii, S. iniae and A. niger in methanolic and ethanolic extracts of bitter leaves. The result of the phytochemical screening shows the presence of saponins, phenols, flavonoids, amino acids but triterpenes and steroids were not detected in the methanolic and ethanolic extracts of almond leaves. Minimum inhibitory concentrations of methanolic and ethanolic extracts of almond and bitter leaves on the bacteria tested were $1000 \mu \mathrm{g} / \mathrm{ml}$ respectively. This investigation provides information on using almond and bitter leaves extracts to control bacterial diseases in aquaculture and it could be concluded that the methanolic and ethanolic extracts of almond and bitter leaves shows promise as an alternative antimicrobial source for use in veterinary medicine.

Keywords: Antimicrobial; Almond Leaves; Bitter Leaves; Phytochemical; Fish Pathogen 


\section{International Journal of Oceanography \& Aquaculture}

Abbreviations: PDA: Potato Dextrose Agar; ANOVA: Analysis of Variance; SPSS: Statistical Package for Social Science.

\section{Introduction}

Aquaculture has been a growing activity for the last 20 years worldwide and this impressive development has been attended by some practices potentially damaging to human and animal health [1]. The large-scale settings of aquatic animal husbandry have resulted in an increased antibiotic resistance in bacteria potentially pathogenic to fish and related environment [2-4]. Continuous use of synthetic antibiotics in aquaculture reveals the threats to consumers and non-target organism in the environment $[5,6]$. Treatments of bacterial diseases with various herbs have been safely and widely used in organic agriculture, veterinary and human medicine [7]. Since ancient times, medicinal plants have been used for the treatment of common infectious diseases [8] and treatments with plants having antibacterial activity are a potentially beneficial alternative in aquaculture [5]. Medicinal plants as the alternative agents are effective to treat the infectious diseases and mitigate many of side effects that are associated with synthetic antimicrobials [9]. In addition, plant-derived phyto-medicines provide a cheaper source for treatment and greater accuracy than chemotherapeutic agents [9]. Among the common fish pathogens are P. aeruginosa, A. hydrophila etc. that cause infectious diseases. Aeromonas hydrophila is one of the most common bacterial pathogens in freshwater fish and has been recognized to be the aetiological agent of several distinct pathological conditions including tail/fin rot and hemorrhagic septicemia especially in freshwater and ornamental fish [10]. The ability of some herbs and seaweeds to inhibit activity of bacteria having potential interest as fish pathogens has been documented $[1,6,7,11$ 13]. Most diseases in fishes are due to poor water quality, stress and over-crowding which lowered the immune system because the presence of microbes [14]. Terminalia catapa and Vernonia amygdalina exhibited a wide range of pharmacological activities including antibacterial, antifungal, antiprotozoal, antidiabetic, anti-cancer, antiinflammatory and antioxidant $[15,16]$. However, there is little or no information on their uses in fish farming. Hence, this study was assessed to evaluate the effectiveness of $T$. catappa and $V$. amygdalina as antimicrobial agents in treating infectious fish diseases.

\section{Materials and Methods}

\section{Plant Collection}

The following plants were used in the study; almond leaves and bitter leaves. These plants were obtained in Ala quarters, Akure, Ondo State and were identified by $\mathrm{Dr}$ D. O. Aworinde in the Department of Biological Sciences (Botany Programme), Ondo State University of Science and Technology, Okitipupa.

\section{Preparation and Extraction of Plant Materials}

Leaves Extraction: The extractions of almond and bitter leaves were done as described by Ajaiyeoba and Fadare [17]. The air-dried almond leaves and bitter leaves were grounded with a hammer mill and $200 \mathrm{~g}$ of the fine powder of these plant leaves were soaked in $1000 \mathrm{ml}$ of ethanol and methanol for 48 hours. These plant leaves were proper mixed with ethanol and methanol at regular interval for homogeneity, filtered, using a sterile muslin cloth after which the extracts was obtained, air-dried and store at $25^{\circ} \mathrm{C}$ until required.

Media Preparation: Media such as Nutrient agar (Oxoid, Germany), Potato Dextrose agar (Oxoid, Germany), MacConkey agar (Oxoid, Germany), and Nutrient broth (Oxoid, Germany) used were prepared according to manufacturer's instruction. All these media are allowed to cool after sterilization to about $45^{\circ} \mathrm{C}$ before pouring into petri dishes.

\section{Source of Micro Organisms}

The microorganisms isolated from C. gariepinus were A. hydrophila, P. aeruginosa, S. iniae and S. aureus. The isolation and characterization of bacteria using biochemical test was carried out at Microbiology Laboratory, Faculty of Science and University of Ibadan. Aspergillus Niger and S. albus were collected from the laboratory stock of the Department of Biological sciences, Ondo State University of Science and Technology, Okitipupa. The pure cultures were labeled, sub-cultured on nutrient agar slants and nutrient broth(s) and potato dextrose agar (PDA), preserved in the refrigerator at $4^{\circ} \mathrm{C}$ until it is require for study.

\section{Antimicrobial Assay}

A well diffusion assay as described by Bello OS, et al. [18] was used. Pre-poured indicator pathogen $(4 \mathrm{~mm}$ depth) was overlaid with a $10 \mathrm{ml}$ soft agar $(0.7 \%)$ lawn of indicator culture (thus generating a potential mat for the indicating of bacteria). Wells of $10 \mathrm{~mm}$ diameter were cut into these agar plates using cork borer and $0.1 \mathrm{ml}$ of these 


\section{International Journal of Oceanography \& Aquaculture}

plants extract was placed into each well [18]. Distilled water was used as negative control while antibiotics, chloramphenicol $(0.1 \mu \mathrm{g}$ and $0.3 \mu \mathrm{g})$ were used as positive control. The plates were examined for zones of inhibition which was scored positive, if the width of the clear zone was $10 \mathrm{~mm}$ or longer. The diameter of the inhibition zones were taken to be proportional to the logarithm of the antimicrobial compounds in almond and bitter leaves and expressed as the $\log _{10} \mathrm{CFU} / \mathrm{ml}$.

\section{Isolation of Microorganism / Counts}

The gills, skin, intestine and liver sample of $C$. gariepinus were separately macerated and put into sterile clapped test tube containing sterilized distilled water and homogenized [19]. Serial dilution was carried out and $1 \mathrm{ml}$ each from $10^{-3}$ to $10^{-5}$ dilution factors were dispersed into petri dishes that were appropriately labeled and molten sterilized medium was poured aseptically into petri dish. The plates were swirled gently forever distribution of inocula and allowed to set / gel and then incubated at $37^{\circ} \mathrm{C}$ for 24 hours. The organisms grew into visible different colonies after 24 hours. Enterobacteriacea and Total viable counts were determined, the result were expressed in $\log _{10} \mathrm{CFU} / \mathrm{g}$.

\section{Minimum Inhibitory Concentration}

Minimum inhibitory concentration of almond and bitter leaves was carried out using Double dilution of $2000 \mu \mathrm{g} / \mathrm{ml}$ of these plants extract were made in $2 \mathrm{ml}$ volume of broth to $3.96 \mu \mathrm{g} / \mathrm{ml}$. One row of the test was inoculated with $0.02 \mathrm{ml}$ of 1 in 10 dilution of the overnight broth culture of the organism [18]. The test was incubated at $37^{\circ} \mathrm{C}$ for 24 hour aerobically. The minimum inhibitory concentration was the lowest concentration that prevented the growth of bacterial after 24 hour incubation [20].

\section{Phytochemical Screening}

\section{Detection of Saponins:}

a) Froth Test: Extracts were diluted with distilled water to $20 \mathrm{ml}$ and this was shaken in a graduated cylinder for 15 minutes. Formation of $1 \mathrm{~cm}$ layer of foam indicates the presence of saponins.

b) Foam Test: Extract of $0.5 \mathrm{~g}$ was shaken with $2 \mathrm{ml}$ of water. If foam produced persists for ten minutes it indicates the presence of saponins.

Detection of Phenols Ferric Chloride Test: Extracts were treated with 3-4 drops of ferric chloride solution. Formation of bluish black colour indicates the presence of phenols.
Tannins: Extract of $0.1 \mathrm{~g}$ was taken up in $10 \mathrm{ml}$ distilled water, and filtered. Then a few drops of ferric chloride $\left(\mathrm{FeCl}_{2}\right)$ reagent were added to $1 \mathrm{ml}$ of the filtrate. The mixture was observed for the formation of blue, blueblack, green or green-black colouration or precipitate.

\section{Detection of Flavonoids}

a) Alkaline Reagent Test: Extracts were treated with few drops of sodium hydroxide solution. Formation of intense yellow colour, which becomes colourless on addition of dilute acid $(\mathrm{HCl})$, indicates the presence of flavonoids.

Glucosinolates: Extract of $0.1 \mathrm{~g}$ was dissolved in $5 \mathrm{ml}$ of chloroform followed by filtration as described by Adeoye BA, et al. [21] method. Concentration tetraoxosulphate (iv) acid (Sulphuric acid) was carefully layered at the bottom of the tube without disturbing the solution. It was observed for the formation of a sharp brown ring at the chloroform/sulphuric acid interface.

Test for Triterpenes and Steroids:

a) The Salkowski Test: Extract of $3 \mathrm{ml}$ was warmed in 5 $\mathrm{ml}$ of chloroform for 30 minutes. The chloroform solution was then treated with a small volume of concentrated tetraoxosulphate (iv) acid $\left(\mathrm{H}_{2} \mathrm{SO}_{4}\right)$ and shaken. The red colour produced within a few minutes indicated a positive reaction.

\section{Detection of Proteins and Aminoacids}

a) Xanthoproteic Test: The extracts were treated with few drops of conc. Nitric acid. Formation of yellow colour indicates the presence of proteins.

\section{Statistical Analysis}

The microbial load of fish tissue (skin, gills, intestine and liver) and antimicrobial and antifungal activities (diameter of zone of inhibition, $\mathrm{mm}$ ) of almond and bitter leaves against tested pathogens resulting from the experiment were subjected to one way analysis of variance (ANOVA) using SPSS (Statistical Package for Social Science version 15.0)

\section{Results}

\section{Determination of Phytochemical in Almond and Bitter Leaves}

Phytochemical screening of almond and bitter leaves for metabolites showed the presence of tannins, saponins, flavonoids, phenol, protein and amino acids while glucosinolates, triterpenes and steroids were not detected in almond leaves but present in methanolic and ethanolic extract of bitter leaves. The values of these metabolites 
were in abundant quantity (+++), moderate quantity (++)

and low quantity (+) in both plants as shown in Table 1.

Table1: Phytochemical screening of methanolic and ethanolic extracts of almond leaves and bitter leaves.

\begin{tabular}{|c|c|c|c|c|}
\hline & Phytochemical & Test Used & Ethanol & Methanol \\
\hline \multirow{8}{*}{ Almond leaves } & \multirow{2}{*}{ Saponins } & Froth test & ++ & ++ \\
\hline & & Foam test & + & + \\
\hline & Phenols & Ferric chloride test & + & + \\
\hline & Flavonoids & & + & + \\
\hline & Tannins & & + & + \\
\hline & Glucosinolates & & - & - \\
\hline & Steroids and triterpenes & & - & - \\
\hline & Protein and amino acid & Xanthoproteic test & + & + \\
\hline \multirow{8}{*}{ Bitter leaves } & \multirow{2}{*}{ Saponins } & Froth test & +++ & +++ \\
\hline & & Foam test & +++ & +++ \\
\hline & Phenols & Ferric chloride test & + & + \\
\hline & Flavonoids & & + & + \\
\hline & Tannins & & + & + \\
\hline & Glucosinolates & & + & + \\
\hline & Steroids and triterpenes & & + & + \\
\hline & Protein and amino acid & Xanthoproteic test & + & + \\
\hline
\end{tabular}

Keys: $+++=$ Present in high quantity, $++=$ moderately present, $+=$ present in low quantity, - = Negative or not present.

\section{Antibacterial Activity of Almond and Bitter Leaves Extracts}

The result revealed that the methanolic and ethanolic extracts of almond and bitter leaves showed antibacterial activities against the pathogens tested except $S$. aureus and S. albus that did not show a diameter of inhibition zone in ethanolic extracts of almond leaves. Also, S. iniae, S. albus, A. hydrophila, B. subtilis and S. typhii were not present in the methanolic and ethanolic extracts of bitter leaves. This was represented in Table 2.

Table 2: Antibacterial activity (diameter of zone of inhibition, $\mathrm{mm}$ ) of methanolic and ethanolic extract of almond and bitter leaves against isolates obtained from C. gariepinus, using distilled water as negative control and chloramphenicol as positive control.

\begin{tabular}{|c|c|c|c|c|c|c|}
\hline & Pathogens & Methanol & Ethanol & Control & $\begin{array}{c}\text { Control 2 } \\
\text { (chloramphenicol } \\
\mathbf{1 0 m g} / \mathbf{m l} \text { ) }\end{array}$ & $\begin{array}{c}\text { Control 2 } \\
\text { (chloramphenicol } \\
\mathbf{3 0 m g / m l}\end{array}$ \\
\hline \multirow{5}{*}{ Almond leaves } & S. aureus & $35.00 \pm 0.03$ & - & - & $13.00 \pm 0.02$ & $35.50 \pm 0.01$ \\
\cline { 2 - 7 } & S. albus & $20.00 \pm 0.01$ & - & - & $11.00 \pm 0.01$ & $35.00 \pm 0.02$ \\
\cline { 2 - 7 } & P. aeruginosa & $15.00 \pm 0.05$ & $15.00 \pm 0.01$ & - & - & - \\
\cline { 2 - 7 } & S. iniae & $15.00 \pm 0.05$ & $15.00 \pm 0.05$ & - & $16.00 \pm 0.05$ & $40.00 \pm 0.01$ \\
\cline { 2 - 7 } & B. hydrophila & $25.00 \pm 0.10$ & $20.00 \pm 0.10$ & - & $14.50 \pm 0.03$ & $43.00 \pm 0.03$ \\
\cline { 2 - 7 } & E. coli & $20.00 \pm 0.06$ & $8.00 \pm 0.06$ & - & $12.80 \pm 0.07$ & $38.00 \pm 0.01$ \\
\hline
\end{tabular}




\section{International Journal of Oceanography \& Aquaculture}

\begin{tabular}{|c|c|c|c|c|c|c|}
\hline & S. typhii & $25.00 \pm 0.01$ & $10.00 \pm 0.01$ & - & $15.00 \pm 0.02$ & $47.00 \pm 0.01$ \\
\hline & S. aureus & $7.00 \pm 0.02$ & $7.00 \pm 0.01$ & - & $13.00 \pm 0.02$ & $35.50 \pm 0.01$ \\
\cline { 2 - 7 } & S. albus & - & - & - & $11.00 \pm 0.01$ & $35.00 \pm 0.02$ \\
\cline { 2 - 7 } & P. aeruginosa & $11.00 \pm 0.01$ & $11.00 \pm 0.03$ & - & - & - \\
\cline { 2 - 7 } & S. iniae & - & - & - & $16.00 \pm 0.05$ & $43.00 \pm 0.01$ \\
\cline { 2 - 7 } & A. hydrophila & - & - & - & $14.50 \pm 0.03$ & $40.00 \pm 0.03$ \\
\cline { 2 - 7 } & B. subtilis & - & - & - & $12.80 \pm 0.07$ & $38.00 \pm 0.01$ \\
\cline { 2 - 7 } & E. coli & $7.00 \pm 0.04$ & $7.00 \pm 0.02$ & - & $14.00 \pm 0.01$ & $43.00 \pm 0.02$ \\
\cline { 2 - 7 } & S. typhii & - & - & - & $15.00 \pm 0.02$ & $47.00 \pm 0.01$ \\
\hline
\end{tabular}

Keys: - = no diameter of zone of inhibition.

\section{Microbial Load in C. gariepinus}

The microbial load of organs in the fish varies distinctively. The result revealed that the total viable counts were generally higher than the enterobacteriacea counts. The highest value recorded was in the gills, followed by the skin, the least value recorded in the liver. This was shown in Table 3.

Table 3: Microbial load of C. gariepinus (liver, skin, intestine and gills).

\begin{tabular}{|c|c|c|}
\hline \multirow{2}{*}{ Organ } & Organism & Microbial $\left.\mathbf{l o a d}_{\mathbf{~}} \log _{\mathbf{1 0}} \mathbf{C F U} / \mathbf{g}\right)$ \\
\hline \multirow{2}{*}{ Liver } & Enterobacteriacea counts & $5.88 \pm 0.50$ \\
\cline { 2 - 3 } & Total viable counts & $6.26 \pm 1.22$ \\
\hline \multirow{2}{*}{ Skin } & Enterobacteriacea counts & $6.67 \pm 0.66$ \\
\cline { 2 - 3 } & Total viable counts & $6.92 \pm 0.84$ \\
\hline \multirow{2}{*}{ Intestine } & Enterobacteriacea counts & $6.33 \pm 0.79$ \\
\cline { 2 - 3 } & Total viable counts & $6.63 \pm 0.66$ \\
\hline \multirow{2}{*}{ Gills } & Enterobacteriacea counts & $6.95 \pm 0.54$ \\
\cline { 2 - 3 } & Total viable counts & $7.19 \pm 0.88$ \\
\hline \multirow{2}{*}{ Control } & Enterobacteriacea counts & - \\
\cline { 2 - 3 } & Total viable counts & - \\
\hline
\end{tabular}

\section{Determination of Minimum Inhibitory Concentration Assay of Methanolic and Ethanolic Extracts of Almond and Bitter Leaves on Isolated Fish Pathogens}

The result of the experiment showed that minimum inhibitory concentration of $1000 \mu \mathrm{g} / \mathrm{ml}$ of methanolic and ethanolic extract of almond leaves and bitter leaves was the minimum concentration that prevents the growth of bacteria after 24 hours of incubation. This is shown in Tables 4A \& B.

Table 4A: The minimum inhibitory concentration assay of methanolic and ethanolic extract of almond leaves on isolated fish pathogen.

\begin{tabular}{|c|c|c|c|c|c|c|c|c|c|c|c|c|c|c|c|c|c|c|c|c|}
\hline \multicolumn{21}{|c|}{ Minimum inhibitory concentration in $\mu \mathrm{g} / \mathrm{ml}$} \\
\hline \multicolumn{11}{|c|}{ Methanol } & \multicolumn{10}{|c|}{ Ethanol } \\
\hline Pathogens & 2000.0 & 1000.0 & 500.0 & 250.0 & 125.0 & 62.5 & 31.25 & 15.63 & 7.81 & 3.96 & 2000.0 & 1000.0 & 0500.0 & 250.0 & 125.0 & 62.5 & 31.25 & 15.63 & 7.81 & 3.96 \\
\hline $\begin{array}{c}\text { Staphylococcus } \\
\text { aureus }\end{array}$ & - & - & - & - & - & + & + & + & + & + & - & - & - & + & + & + & + & + & + & + \\
\hline $\begin{array}{c}\text { Staphylococcus } \\
\text { albus }\end{array}$ & - & - & - & + & + & + & + & + & + & + & - & + & + & + & + & + & + & + & + & + \\
\hline $\begin{array}{c}\text { Pseudomonas } \\
\text { aeruginosa }\end{array}$ & - & - & + & + & + & + & + & + & + & + & - & - & - & + & + & + & + & + & + & + \\
\hline
\end{tabular}




\section{International Journal of Oceanography \& Aquaculture}

\begin{tabular}{|c|c|c|c|c|c|c|c|c|c|c|c|c|c|c|c|c|c|c|c|c|}
\hline $\begin{array}{c}\text { Streptococcus } \\
\text { iniae }\end{array}$ & - & + & + & + & + & + & + & + & + & + & - & + & + & + & + & + & + & + & + & + \\
\hline $\begin{array}{c}\text { Aeromonas } \\
\text { hydrophila }\end{array}$ & - & + & + & + & + & + & + & + & + & + & - & - & - & - & + & + & + & + & + & + \\
\hline Bacillus subtilis & - & - & - & + & + & + & + & + & + & + & - & + & + & + & + & + & + & + & + & + \\
\hline Eschericia coli & - & - & - & - & + & + & + & + & + & + & - & + & + & + & + & + & + & + & + & + \\
\hline Salmonella typhi & - & - & - & - & + & + & + & + & + & + & - & + & + & + & + & + & + & + & + & + \\
\hline Control & - & - & - & - & - & - & - & - & - & - & - & - & - & - & - & - & - & - & - & - \\
\hline
\end{tabular}

Keys: + =Presence of growth or medium turbidity, - =No growth or turbidity observed.

Table 4B: Minimum inhibitory concentration assay of methanolic and ethanolic extracts of bitter leaves on isolated fish pathogen.

\begin{tabular}{|c|c|c|c|c|c|c|c|c|c|c|c|c|c|c|c|c|c|c|c|c|}
\hline \multicolumn{21}{|c|}{ Minimum inhibitory concentration in $\mu \mathrm{g} / \mathrm{ml}$} \\
\hline \multicolumn{11}{|c|}{ Methanol } & \multicolumn{10}{|c|}{ Ethanol } \\
\hline Pathogens & $\begin{array}{c}2000 \\
0\end{array}$ & $\begin{array}{c}1000 \\
0\end{array}$ & 500.0 & 250.0 & 125.0 & 62.5 & 31.25 & 15.63 & 7.81 & 3.96 & $\begin{array}{c}2000 \\
0\end{array}$ & $\begin{array}{c}1000 \\
0\end{array}$ & 500.0 & 250.0 & 125.0 & 62.5 & 31.25 & 515.63 & 7.81 & 3.96 \\
\hline $\begin{array}{c}\text { Staphylococcus } \\
\text { aureus }\end{array}$ & - & - & + & + & + & + & + & + & + & + & - & - & - & - & + & + & + & + & + & + \\
\hline $\begin{array}{c}\text { Staphylococcus } \\
\text { albus }\end{array}$ & - & - & - & + & + & + & + & + & + & + & - & - & - & + & + & + & + & + & + & + \\
\hline $\begin{array}{c}\text { Pseudomonas } \\
\text { aeruginosa }\end{array}$ & - & - & + & + & + & + & + & + & + & + & - & - & + & + & + & + & + & + & + & + \\
\hline Streptococcus iniae & - & - & - & + & + & + & + & + & + & + & - & - & + & + & + & + & + & + & + & + \\
\hline $\begin{array}{c}\text { Aeromonas } \\
\text { hydrophila }\end{array}$ & - & + & + & + & + & + & + & + & + & + & - & + & + & + & + & + & + & + & + & + \\
\hline Bacillus subtilis & - & - & + & + & + & + & + & + & + & + & - & - & + & + & + & + & + & + & + & + \\
\hline Escherichia coli & - & - & - & + & + & + & + & + & + & + & - & - & - & + & + & + & + & + & + & + \\
\hline Salmonella typhii & - & - & - & + & + & + & + & + & + & + & - & - & - & + & + & + & + & + & + & + \\
\hline Control & - & - & - & - & - & - & - & - & - & - & - & - & - & - & - & - & - & - & - & - \\
\hline
\end{tabular}

Keys: + =Presence of growth or medium turbidity $\quad$ - =No growth or turbidity observed.

\section{Discussion}

Phytochemical screening of almond leaves and bitter leaves for metabolites showed the presence of tannins, saponins, flavonoids, phenol, protein and amino acids while glucosinolates, triterpenes and steroids were not detected in almond leaves but present in methanolic and ethanolic extract of bitter leaves. This result agrees with the report of Udochukwu U, et al., Okokon JE, et al. and Igile $\mathrm{GO}$, et al. who reported the presence of these metabolites [22-24].

Methanolic and ethanolic extracts of almond and bitter leaves showed antibacterial activities against the pathogens tested except $S$. aureus and S. albus that did not show a diameter of inhibition zone in ethanolic extracts of almond leaves. Also, S. iniae, S. albus, A. hydrophila, B. subtilis and $S$. typhii were not present in the methanolic and ethanolic extracts of bitter leaves. This correlates with Kigigah LT, et al., Akharaiyi FC, et al. and Nair R, et al. [25-27]. Almond leaves extracts had highest zone of inhibition compared to bitter leaves extracts. This revealed that almond leaves extract had better antimicrobial potential when compared with bitter leaves. The inhibitory effect on bacteria might be due to the active compound present in almond leaves. This result agrees with the report of Olusola SE, et al., Nargis A, et al. and Turker $\mathrm{AU}$, et al. [28-30] who stated that plant extracts can be used as antimicrobials. The results were compared with the standard antimicrobics Chloramphenicol at $10 \mathrm{mg} / \mathrm{ml}$ and $30 \mathrm{mg} / \mathrm{ml}$ ), the results revealed that Chloramphenicol at $30 \mathrm{mg} / \mathrm{ml}$ had better diameter of zone inhibition when compared with ethanolic and methanolic extracts of almond and bitter leaves. 


\section{International Journal of Oceanography \& Aquaculture}

The organs in a fish have varying number of microorganisms present. Total viable counts of the organs were always higher than the enterobacteriacea counts. Gills was presented to have the highest total viable counts of $\left(7.19 \pm 0.88 \log _{10} \mathrm{CFU} / \mathrm{g}\right)$ among all the organs followed by the skin total viable counts of $\left(6.92 \pm 0.84 \log _{10} \mathrm{CFU} / \mathrm{g}\right)$ due to their exposure to the aquatic environment, with the liver presenting the least value of total viable counts $\left(6.26 \pm 1.22 \log _{10} \mathrm{CFU} / \mathrm{g}\right)$. This result supports the report of Bello OS, et al. and Shalaby AM, et al. [18,19].

The result of the experiment showed that $1000 \mu \mathrm{g} / \mathrm{ml}$ of methanolic and ethanolic extracts of almond leaves and bitter leaves was the minimum concentration that prevents the growth of bacteria after 24 hours incubation. This result supports the report of Olusola SE, et al. and Owolabi MS, et al. [28,31].

\section{Conclusion}

This result revealed that almond leaves and bitter leaves had antimicrobial properties. However, the methanolic extracts of almond leaves had higher antimicrobial property when compared with the bitter leaves. Also, the minimum inhibitory concentration of $1000 \mu \mathrm{g} / \mathrm{ml}$ were recorded in methanolic and ethanolic extracts of almond and bitter leaves at 24 hours old incubation. This study justify the use of almond and bitter leaves as therapeutic and antimicrobial agents to treat fish pathogenic diseases that have developed resistance to existing synthetic antimicrobial agents.

\section{References}

1. Naylor R, Burke M (2005) Aquaculture and ocean resources: raising tigers of the sea. Annual Review of Environmental Resources 30: 185-218.

2. Cabello FC (2006) Heavy use of prophylactic antibiotics in aquaculture: A growing problem for human and animal health and for the environment. Environ Microbiol 8(7): 1137-1144.

3. Alcaide E, Blasco MD, Esteve C (2005) Occurrence of drug-resistant bacteria in two European Eel farms. Appl Environ Microbiol 71(6): 3348-3350.

4. Alderman DJ, Hastings TS (1998) Antibiotic use in aquaculture: development of antibiotic resistance potential for consumer health risks. Int J Food Sci Technol 33(2): 139-155.
5. Abutbul S, Goldhirsh GA, Barazani O, Ofir R, Zilberg D (2005) Screening of desert plants for use against bacterial pathogens in fish. Isr J Aquacult Bamid 57(2): 71-80.

6. Muniruzzaman M, Chowdhury MBR (2004) Sensitivity of fish pathogenic bacteria to various medicinal herbs. Bangladesh Journal of Veterinary Medicine 2(1): 75-82.

7. Direkbusarakom S (2000) Application of herbs for aquaculture in Asia. The AAHRI Newsletters 9(2): 3-5.

8. Rios JL, Recio MC (2005) Medicinal plants and antimicrobial activity. J Ethnopharmacol 100(1-2): 80-84.

9. Punitha SMJ, Babu MM, Sivaram V, Shankar VS, Dhas SA, et al. (2008) Immunostimulating influence of herbal biomedicines on nonspecific immunity in Grouper Epinephelus tauvina juvenile against Vibrio harveyi infection. Aquacult Int 16(6): 511-523.

10. Austin B, Austin DA (2007) Bacterial Fish Pathogens: Disease of Farmed and Wild Fish. Praxis Publishing, UK, pp: 581.

11. Dubber D, Harder T (2008) Extracts of Ceramium rubrum, Mastocarpus stellatus and Laminaria digitata inhibit growth of marine and fish pathogenic bacteria at ecologically realistic concentrations. Aquaculture 27(4): 196-200.

12. Bansemir A, Blume M, Schröder S, Lindequist U (2006) Screening of cultivated seaweeds for antibacterial activity against fish pathogenic bacteria. Aquaculture 252: 79-84.

13. Borisutpeth P, Kanbutra P, Weerakhun S, Sarachoo K, Porntrakulpipat S (2005) Antibacterial activity of Thai medicinal plant extracts on Aeromonas hydrophila and Streptococcus agalactiaee isolated from diseased tilapia. In: Abstracts of 31st Congress on Science and Technology of Thailand at Suranaree University of Technology, Thailand, pp: 18-20.

14. Baticados MCL, Lavilla-Pitogo CR, Cruz-Lacierda ER, de la Pena LD, Sunaz NA (1990) Studies on the chemical control of luminous bacteria Vibrio harveyi and V. splendidus isolated from diseased Penaeus monodon larvae and rearing water. Dis Aquat Org 9: 133-139. 


\section{International Journal of Oceanography \& Aquaculture}

15. Ijeh II, Ejike CC (2011) Current perspectives on the medicinal potentials of Vernonia amygdalina Del. Journal of Medicinal Plant Research 5(7): 1051-1061.

16. Akinpelu DA, Onakoya TM (2006) Antimicrobial activities of medicinal plants used in folklore remedies in South-western. African Journal of Biotechnology 5(11): 1078-1081.

17. Ajaiyeoba EO, Fadare DA (2006) Antimicrobial potential of extracts and fractions of the African walnut - Tetracarpidium conophorum. African Journal of Biotechnology 5(22): 2322-2325.

18. Bello OS, Olaifa FE, Emikpe BO, Ogunbanwo ST (2013) Potentials of walnut (Tetracarpidium conophorum Mull. Arg) leaf and onion (Allium cepa Linn) bulb extracts as antimicrobial agents for fish. African Journal of Microbiology Research 7(19): 2027-2033.

19. Shalaby AM, Khattab YA, Abdel-Rahman AM (2006) Effects of garlic (Allium sativum) and chloramphenicol on growth performance, physiological parameters and survival of Nile tilapia (Oreochromis niloticus). Journal of Venomous Animal Toxins including Tropical Diseases 12(2): 172-201.

20. Osoba AO (1979) The control of gonococcal infections and other sexually transmitted diseases in developing countries-with particular reference to Nigeria. Nigeria Journal of Medical Science 2: 127-133.

21. Adeoye, B. A and Oyedapo, 0. 0. (2004). Toxicity of erythrophleum stem-bark: role of alkaloids fraction. Afr J Trad CAM 1: 45-54.

22. Udochukwu U, Omeje FI, Uloma IS, Osiewe FD (2015) Phytochemical analysis of Vernonia amygdalina and Ocimum gratissimum extracts and their antibacterial activity on some drug resistant bacteria. American Journal of Research Communication 3(5): 225-235.

23. Okokon JE, Onah MI (2004) Pharmacological studies on root extract of Vernonia amygdalina. Nigerian Journal of Natural Products and Medicine 8: 60-62.
24. Igile GO, Oleszek WI, Jurysta MR, Burda SI, Farifunso $\mathrm{ME}$, et al. (1994) Flavonoids from Vernonia amygdalina and their antioxidant activities. Journal of Agricultural and Food Chemistry 42: 2445-2448.

25. Kigigha LT, Ebubechukwu O (2015) Antibacterial activity of bitter leaf (Vernonia amygdalina) soup on Staphylococcus aureus and Escherichia coli). Sky Journal of Microbiology Research 3(4): 041-045.

26. Akharaiyi FC, Ilori RM, Adesida JA (2011) Antibacterial effect of Terminalia catappa on some selected pathogenic bacteria. Int J Pharm Biomed Res 2(2): 64-67.

27. Nair R, Chanda S (2008) Antimicrobial activity of Terminalia catappa, Manilkara zapota and Piper betel leaves extracts. Indian J Pharm Sci 70(3): 390-393.

28. Olusola SE, Emikpe BO, Olaifa FE (2013) The potentials of medicinal plants extracts as bioantimicrobials in aquaculture. Int J Med Arom Plants 3(3): 404-412.

29. Nargis A, Khatun M, Talukder D (2011) Use of medicinal plants in the remedy of fish diseases. Bangladesh Research Publication Journal 5(3): 192195.

30. Turker AU, Usta C (2008) Biological screening of some Turkish medicinal plants for antimicrobial and toxicity activities. Natural Product Research 22(2): 136-146.

31. Owolabi MS, Lawal OA, Ogunwande IA, Hauser RM, Setzer WN (2013) Chemical composition of the leaf essential oil of Terminalia catappa L. growing in South-western Nigeria. American Journal of Essential Oil and Natural Products 1(1): 51-54. 